\title{
Flavobacterium frigidarium sp. nov., an aerobic, psychrophilic, xylanolytic and laminarinolytic bacterium from Antarctica
}

\footnotetext{
1 The School of Sciences, University of Sunderland, Sunderland SR1 3SD, UK

2 British Antarctic Survey, Natural Environment Research Council, High Cross, Madingley Road, Cambridge CB3 OET, UK

3 School of Applied and Molecular Sciences, University of Northumbria at Newcastle, Ellison Building, Newcastle upon Tyne NE1 8ST, UK
}

\author{
David R. Humphry, ${ }^{1}$ Alison George, ${ }^{2}$ Gary W. Black ${ }^{3}$ \\ and Stephen P. Cummings ${ }^{1}$
} Author for correspondence: Stephen P. Cummings. Tel: +44 191515 3380. Fax: +44 1915152534.
e-mail: stephen.cummings@sunderland.ac.uk
Keywords: Flavobacterium frigidarium, psychrophilic, xylanolytic, laminarinolytic, halotolerant

\section{INTRODUCTION}

Psychrophilic bacteria have been isolated from environments such as Antarctica and deep-sea sediments (Feller et al., 1996). They are interesting because of their physiological adaptations, which enable them to survive at low temperatures (below $5{ }^{\circ} \mathrm{C}$ ). These adaptations include cold-shock proteins, polyunsaturated branched-chain fatty acids in the cytoplasmic membrane (Russell \& Nichols, 1999) and more efficient enzymes (Feller et al., 1996). The hydrolysis of organic polymers at low temperatures has received little attention until recently (Mountfort et al., 1997). This is despite the fact that carbohydrase-

The GenBank accession number for the 16S rDNA sequence of Flavobacterium frigidarium is AF162266. producing organisms must play an important role in the cycling of organic carbon in cold environments. To date, only one carbohydrase enzyme - an $\alpha$-amylase from a psychrophilic bacterium - has been thoroughly characterized. This enzyme exhibited adaptive features, such as greater activity at $4{ }^{\circ} \mathrm{C}$ and increased thermolability relative to its mesophilic counterparts (Feller et al., 1994).

This study on the hydrolysis of cellulose, pectin, laminarin and xylan among psychrophilic marine bacteria has led to the isolation of a psychrophilic, xylanolytic and laminarinolytic bacterium (strain $A 2 i^{\mathrm{T}}$ ). Xylan is the major hemicellulose in macroalgae and plant cell walls; it is hydrolysed by endo- $\beta 1,4-$ xylanases, which can be classified as either glycosyl hydrolase family 10 or family 11 enzymes (Charnock et al., 1997). Laminarin is a storage polymer of Phaeophyta (brown marine algae) and is an essentially 
linear polymer of $(1 \rightarrow 3)$ - $\beta$-glucosidic linkages joining glucose residues, often terminating with D-mannitol.

Many mesophilic and thermophilic xylanases have been investigated and cloned, but there are few reports of xylanolytic activity in an aerobic psychrophilic bacterium. There have been no reports, to our knowledge, of an aerobic, laminarinolytic psychrophilic bacterium. The xylanase activity has the characteristic properties of cold active enzymes, e.g. a greater catalytic activity at temperatures below $20{ }^{\circ} \mathrm{C}$ and a much reduced thermostability at $37^{\circ} \mathrm{C}$ and above, relative to the xylanases of the mesophile Pseudomonas fluorescens subsp. cellulosa (Humphry et al., 1999). Enzyme activity analysis has also shown that the laminarinase has similar properties and so can be described as a psychrophilic enzyme (D. R. Humphry, unpublished data).

The isolate was examined on the basis of its phenotypic and genotypic properties. Phenotypic characteristics of the bacterium suggested that it was a member of the Flavobacterium genus. Sequence analysis and DNADNA hybridization of the $16 \mathrm{~S}$ rDNA showed that its closest relation, Flavobacterium columnare, was too distant to be the same species. It is proposed that $A 2 i^{\mathrm{T}}$ be designated as the type strain of Flavobacterium frigidarium sp. nov.

\section{METHODS}

Sampling method. Samples of shallow-water marine sediment were collected off Adelaide Island, Antarctica $\left(67^{\circ} 34^{\prime} \mathrm{S}, 68^{\circ} 07^{\prime} \mathrm{W}\right)$. Samples were prepared for transport to the UK by lyophilization $(2 \mathrm{~g})$ and sealed in an airtight container, and were imported to the UK under Ministry of Agriculture and Fisheries licence PHL 130/2653 (4/1998).

Methods for enrichment and isolation. Approximately $1 \mathrm{~g}$ lyophilized sediment was inoculated into a $50 \mathrm{ml}$ volume of xylan minimal medium (XMM) in a $250 \mathrm{ml}$ Erlenmeyer flask. $\mathrm{XMM}$ is minimal medium (MM) containing the following (w/v): $0.002 \% \mathrm{FeSO}_{4}, 0.02 \% \mathrm{MgSO}_{4}, 0.075 \%$ $\mathrm{KNO}_{3}, 0.05 \% \mathrm{~K}_{2} \mathrm{HPO}_{4}$ and $0.004 \% \mathrm{CaCl}_{2}$, plus $0.5 \%$ soluble xylan. The $\mathrm{pH}$ was adjusted to $7 \cdot 2$ with $1 \mathrm{M} \mathrm{NaOH}$ or $1 \mathrm{M} \mathrm{HCl}$. The solid medium was prepared by the addition of $1.5 \%(\mathrm{w} / \mathrm{v})$ Oxoid technical agar no. 3 . The media were autoclaved at $121^{\circ} \mathrm{C}$ for $15 \mathrm{~min}$. Enrichment broths were incubated at $4{ }^{\circ} \mathrm{C}$ for 3 weeks on an orbital shaker (150 r.p.m.). The enrichment culture was streaked onto $\mathrm{XMM}$ agar plates, which were then incubated at $4{ }^{\circ} \mathrm{C}$ for $10 \mathrm{~d}$. Individual colonies were picked off and inoculated into $50 \mathrm{ml} \mathrm{XMM} \mathrm{broth;} \mathrm{this} \mathrm{process} \mathrm{was} \mathrm{repeated} \mathrm{until} \mathrm{pure}$ cultures were obtained.

Xylanase activity was determined by staining of the XMM plates with $1 \%(\mathrm{w} / \mathrm{v})$ Congo red and destaining with $1 \mathrm{M}$ $\mathrm{NaCl}$ solution, which reveals haloes around xylanolytic colonies. Xylanase and laminarinase activities were quantified using the dinitrosalicylic acid assay (Miller, 1959) on supernatants from XMM and carboxymethyl-curdlan (Megazyme) MM $A 2 i^{\mathrm{T}}$ cultures, respectively.

Basic characterization. Standard bacteriological methods were use throughout. Colonies from XMM agar were Gramstained and examined by light-microscopy. Production of hydrogen sulphide was tested on slopes and stabs of triple- sugar iron agar (CM277; Oxoid) and Kligler iron agar (CM33; Oxoid). DNase agar was made and DNase activity was tested for using the protocol described previously (Bridson, 1998). Egg-yolk agar was made using egg-yolk emulsion (SR47; Oxoid).

Acid- and gas production from glucose, fructose, xylose, mannitol and maltose were tested with incubation at $15^{\circ} \mathrm{C}$ for $10 \mathrm{~d}$ and checks every day. Growth on MacConkey agar (CM7; Oxoid) was tested for at 4 and $15^{\circ} \mathrm{C}$. Colony morphology on Anacker-Ordal agar (AOA) was determined (Bernadet et al., 1996), and extracellular galactosamine glycan production was detected using Congo red. Growth of isolate $A 2 i^{\mathrm{T}}$ on nutrient agar (NA) (CM3; Oxoid), trypticase soy agar (TSA) (CM 131; Oxoid), seawater agar (medium 246; DSMZ) and in seawater Lemco broth (medium 627; DSMZ) was tested. Growth on MacConkey agar, NA, TSA, in $\mathrm{MM}$ and XMM broths was also determined for the Flavobacterium species that were most similar on the basis of their 16S rDNA sequences.

The substrate-utilization profile of the bacterium was determined in triplicate at 2 and $10{ }^{\circ} \mathrm{C}$ in MM containing $0.5 \%$ $(\mathrm{w} / \mathrm{v})$ substrate. Certain substrates were added, after sterilization, by inoculating filter-sterilized stock solutions to the required concentration, to prevent caramelization during autoclaving. Carboxymethyl-cellulose (CMcellulose) and soluble xylan were added as solids, as these could be autoclaved. Agar degradation was tested on MM agar at $1.5 \%(\mathrm{w} / \mathrm{v})$. Pullulanase activity was tested for by incorporating $0.5 \%(\mathrm{w} / \mathrm{v})$ red pullulan (Megazyme) and an identical concentration of purified soluble starch in to MM broth agar plates. Endo-1,3- $\beta$-glucanase (laminarinase) activity was tested for by adding $0.5 \%(\mathrm{w} / \mathrm{v})$ Azcl-curdlan (Megazyme) to MM broth agar according to the manufacturer's instructions. The cultures were incubated at 2 and $10{ }^{\circ} \mathrm{C}$ for 2 weeks.

Duplicate API 20NE and API ZYM identification strips were set up as instructed by the manual and incubated at $15^{\circ} \mathrm{C}$ for $3 \mathrm{~d}$. API ZYM strips were set up for isolate $A 2 i^{\mathrm{T}}$ and for the closest valid Flavobacterium species. The flavobacteria tested were grown up on NA at $25^{\circ} \mathrm{C}$. $A 2 i^{\mathrm{T}}$ was grown up on NA and AOA at $15^{\circ} \mathrm{C}$ for two sets of API ZYM tests. All of the strips were incubated at $15^{\circ} \mathrm{C}$ for $15 \mathrm{~h}$ then developed and read.

Pigment characterization. Pigment analysis was performed using the $\mathrm{KOH}$ test (Fautz \& Reichenbach, 1980) and confirmatory testing was done by pigment extraction (Jagannadham et al., 1991), followed by TLC. The mobile phase was $2 \%(\mathrm{v} / \mathrm{v})$ acetone and $98 \%$ light petroleum ether, the stationary phase was silica, and the bands were visualized in an iodine bath. For tentative identification of the pigment, it was necessary to do a spectrophotometric analysis for comparison with published $\lambda_{\max }$ values (Schmidt et al., 1994).

Antibiotic-sensitivity tests. Duplicate antibiotic-sensitivity tests were done using filter-paper disks containing the following: chloramphenicol $(25 \mu \mathrm{g})$, erythromycin $(5 \mu \mathrm{g})$, fusidic acid $(10 \mu \mathrm{g})$, methicillin $(10 \mu \mathrm{g})$, novobiocin $(5 \mu \mathrm{g})$, penicillin $\mathrm{G}(1 \mathrm{U})$, streptomycin $(10 \mu \mathrm{g})$ (Mast Diagnostics), tetracycline $(10 \mu \mathrm{g})$ and ampicillin $(25 \mu \mathrm{g})$ (Sigma). Disks were placed on Luria-Bertani (LB) plates spread with $A 2 i^{\mathrm{T}}$ culture and were then incubated at $15^{\circ} \mathrm{C}$ for $7 \mathrm{~d}$.

Growth was tested against various dissolved antibiotics (see Results) in duplicate at four different concentrations. The appropriate volumes of antibiotic stocks $\left(2 \mathrm{mg} \mathrm{ml}^{-1}\right)$ were 


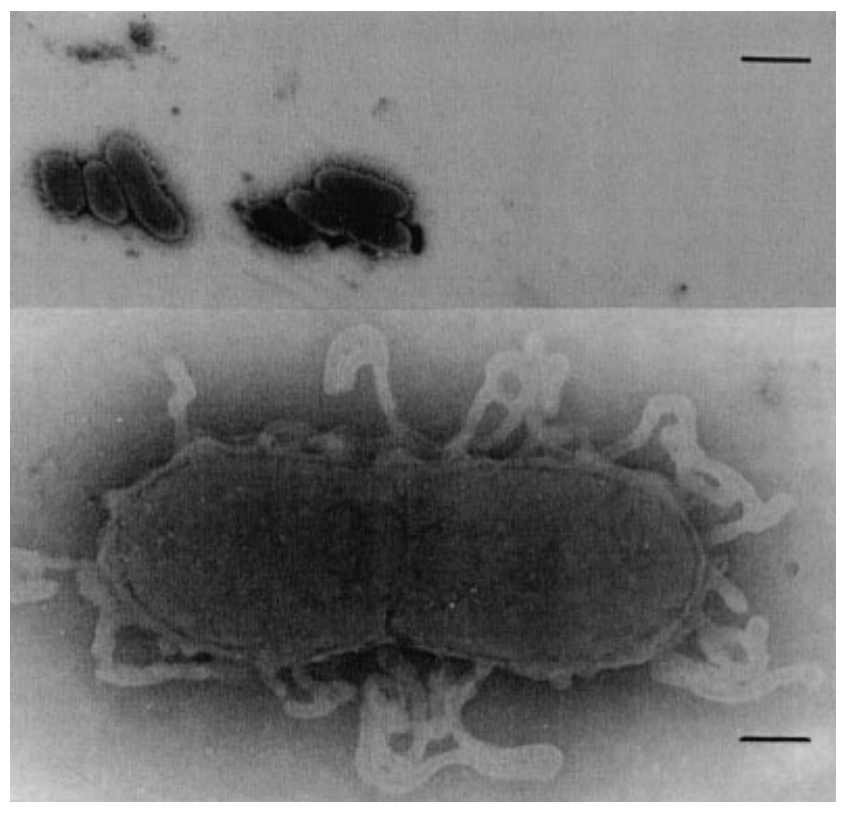

Fig. 1. Negative-stain transmission electron micrographs of Flavobacterium frigidarium cells in exponential growth phase at $10^{\circ} \mathrm{C}$ : (top) a group of cells (bar, $1 \mu \mathrm{m}$ ); (bottom) dividing encapsulated cell (bar, $0.167 \mu \mathrm{m})$.

added to LB agar ( $\mathrm{pH} 7 \cdot 2)$ to give final volumes of $20 \mathrm{ml}$. A discrete $A 2 i^{\mathrm{T}}$ colony (grown at $2{ }^{\circ} \mathrm{C}$ on XMM agar), was then spread onto each plate. The cultures were incubated at 2 and $15^{\circ} \mathrm{C}$ for $14 \mathrm{~d}$.

Temperature, $\mathrm{pH}$, and salinity limits. The specific growth rate of the bacterium was determined in XMM broth at between 0 and $25^{\circ} \mathrm{C}$. The optimal growth temperature was determined by obtaining the mean specific growth rates of three independent cultures grown at each temperature. Growth was monitored by optical density at $660 \mathrm{~nm}$ using a spectrophotometer (LKB).

The growth rate over the $\mathrm{pH}$ range $4 \cdot 25-9.68$ was determined, in duplicate, at a temperature of $15^{\circ} \mathrm{C}$ in $\mathrm{LB}$ broth supplemented with an appropriate buffer. The buffers used were as follows: acetate buffer, $\mathrm{pH} 4$-25-6; PIPES buffer, $\mathrm{pH}$ 5.5-7.5; Tris, $\mathrm{pH} 7-9$; and $\mathrm{Na}_{2} \mathrm{CO}_{3} \mathrm{pH}$ 8.5-9.68. The $\mathrm{pH}$ values of the growth media were checked both after cell inoculation and each time a sample was taken for absorbance testing. A $400 \mu \mathrm{l}$ volume of bacterial cells was used to inoculate each culture; these were obtained from an XMM culture grown up at $2{ }^{\circ} \mathrm{C}$ and washed twice and resuspended in $50 \mathrm{mM}$ buffer at the appropriate $\mathrm{pH}$.

Growth in up to $10 \%(\mathrm{w} / \mathrm{v})$ sodium chloride was determined in triplicate, at $2{ }^{\circ} \mathrm{C}$ in xylose minimal medium (XeMM; MM broth containing $0.5 \%, \mathrm{w} / \mathrm{v}$, xylose) in Anacker-Ordal broth (AOB) and in LB broth.

16S rDNA gene PCR amplification method. The 16S rDNA primers used to obtain the initial PCR product were identical to the Escherichia coli 16S rDNA sequence, between positions 8 and 27 (forward) and 1509 and 1491 (reverse). These primers were 5'-AGA GTT TGA TCC TGG CTC AG-3' and 5'-GGH TAC CTT GTT ACG ACT T-3', respectively. Each PCR reaction contained $1 \times$ Taq buffer, $2.5 \mathrm{U}$ Taq DNA polymerase, $0.2 \mathrm{mM}$ of the four dNTPs (all from Life Technologies), $1 \mu \mathrm{g}$ isolate genomic DNA and $0.5 \mu \mathrm{M}$ each primer. The PCR was done in the presence of 1 ,
2, 3 and $4 \mathrm{mM} \mathrm{MgCl}_{2}$ (Life Technologies). The PCR conditions used were as follows: one cycle at $95^{\circ} \mathrm{C}$ for $3 \mathrm{~min} ; 35$ cycles at $95^{\circ} \mathrm{C}$ for $2 \mathrm{~min} ; 1 \mathrm{~min}$ at $35,38,42$ or $46^{\circ} \mathrm{C}$ (the specific primer annealing temperature); 4 min at $72{ }^{\circ} \mathrm{C}$; then $20 \mathrm{~min}$ at $72{ }^{\circ} \mathrm{C}$.

Cloning and sequencing of the PCR products. The PCR products from two of the 16 PCR reactions (for sequence comparison) were cloned into the pGEM-T 'easy' plasmid (Promega). Insert cloning efficacy was checked and plasmid DNA was extracted from two bacterial clones by using a micro-spin column (Qiagen). Each clone carried a PCR product originating from different PCR reactions. The two plasmid inserts were then sequenced completely, using a DNA sequencer (PE Biosystems). This was done by using the forward and reverse primers for the pGEM-T plasmid, initially; subsequently, oligonucleotide primers were built onto the ends of the resulting sequences. These oligonucleotide primers were 5'-GCC GCG TGC AGG ATG AC-3', 5'-GAC ATG ACT CGC TGG CAA CT-3' and 5'-GTG GCT AAG CGA AAG TGA TAA GTA-3', 5'GGC CGT TCC ACC GTT GAG C-3', respectively. The sequences from the two clones matched, although they were in opposite orientations.

$16 \mathrm{~S}$ rDNA sequence analysis. The $16 \mathrm{~S}$ rDNA sequence of the bacterium was 1391 bases long, with no non-base characters. Its seven closest relatives were individually aligned against it, all columns containing non-base characters were removed, and then the percentage similarities were calculated. The sequence was also aligned against 19 other sequences at once, using the CLUSTAL method in MEGALIGN program (DNAStar), and then all non-base characters were removed manually. This reduced the lengths of the sequences analysed by the PHYLIP and MEGALIGN programs to 1136 bases. The 19 16S rDNA sequences were taken from GenBank and the Ribosomal Database Project (RDP; http://www.cme.msu. $\mathrm{edu} / \mathrm{RDP} / \mathrm{html} /$ index.html). GenBank accession numbers or strain numbers are shown on the dendrogram (see Fig. 2). Computer programs used for phylogenetic analysis included SEQBOOT (1000 replicates), DNADIST (Jukes \& Cantor), NEIGHBOUR (neighbour-joining), CONSENSE (Felsenstein, 1993), DNAPARS (parsimony analysis) and TREEVIEW (Page, 1996). The conserved node frequency data were added to the dendrogram produced by NEIGHBOUR for the original molecular sequence data. Reliable nodes were also found by doing maximum-likelihood, Jin \& Nei and Kimura twoparameter analyses followed by neighbour-joining (Saitou \& Nei, 1987) on the original data, as well as by producing a consensus tree of 1000 replicates by using the normal parsimony method. Nodes that occurred in these trees and in the Jukes \& Cantor dendrogram were marked (see Fig. 2).

Genomic DNA G + C content and DNA-DNA hybridizations. The genomic DNA of the bacterium was extracted using a microcentrifuge separation column (Qiagen). The $\mathrm{G}+\mathrm{C}$ content was determined in triplicate, using a spectrophotometer (LKB) and a thermal denaturation method (Marmur \& Doty, 1962). The DNA was isolated by chromatography (Cashion et al., 1977), then DNA-DNA hybridization was performed as described previously (De Ley et al., 1970), but with a modification (Huss et al., 1983; Escara \& Hutton, 1980). The procedure was performed on a Gilford System model 2600 spectrometer equipped with a Gilford model 2527-R thermoprogrammer and plotter. Finally, renaturation rates were computed using the TRANSFER.BAS program (Jahnke, 1992).

Transmission electron microscopy. A sample of $A 2 i^{\mathrm{T}}$ culture in exponential growth phase was negatively stained with 
$0.7 \%$ sodium silicotungstate solution (Agar Scientific), as described by Brenner \& Horne (1959), and then examined.

Membrane fatty acid identification. Fatty acid methyl esters were prepared from freeze-dried cells (grown up in XMM broth at $15^{\circ} \mathrm{C}$ ) by transmethylation (Komagata \& Suzuki, 1987). They were analysed by GC (UNICAM 610) using a $25 \mathrm{~m}$ BPX70 (SGE) column and a temperature programme of $100-240^{\circ} \mathrm{C}$. Split injection was used along with a flameionization detector; the injector and the detector were maintained at $280{ }^{\circ} \mathrm{C}$. The analyses were performed in triplicate on three independent cultures. Individual fatty acids were identified by using authentic standards, and identities were confirmed by GC-MS.

\section{RESULTS}

\section{Morphological properties}

Colonies of $A 2 i^{\mathrm{T}}$ were bright yellow, raised and had an entire edge on XMM agar; the colonies on AOA, however, were flat, round and entire. Micro-mor- phological properties included the presence of a capsule and pili but no flagella (Fig. 1). The cells are 0.8-2 $\mu \mathrm{m}$ long and 0.5-0.7 $\mu \mathrm{m}$ wide, they occur singly or in pairs and they are non-motile. Cell morphology ranged from coccoid-like cells to fat, medium-length rods. The cells stained Gram-negative and no evidence of spores was detected on any growth medium.

\section{Physiological characteristics}

Isolate $A 2 i^{\mathrm{T}}$ was a psychrophilic, neutrophilic, aerobic, xylanolytic and laminarinolytic bacterium. It was also capable of growth in AOB containing from 0 to $5 \%$ $(\mathrm{w} / \mathrm{v}) \mathrm{NaCl}$, inclusive, in XeMM containing from 0 to $4 \%(\mathrm{w} / \mathrm{v}) \mathrm{NaCl}$, inclusive, and in $\mathrm{LB}$ containing from 0 to $9 \%(\mathrm{w} / \mathrm{v}) \mathrm{NaCl}$, inclusive. Catalase and cytochrome oxidase tests on distinct colonies were positive. There was no nitrate reduction, no indole production and no arginine dihydrolase, urease, DNase or $\beta$ galactosidase activity was detected. The bacterium

\section{Table 1. Some of the phenotypic characteristics of $A 2 i^{\top}$}

+ , All strains positive; - , all strains negative; $(+)$, weakly positive; v, variable among strains; $\mathrm{V}$, variable among references; ND, not determined. For ease of comparison with other validly published Flavobacterium species, the data are presented in the same format as that in Bernadet et al. (1996).

\begin{tabular}{|lc|}
\hline Characteristic & Isolate $\boldsymbol{A 2}^{\mathbf{T}}$ \\
\hline Anacker-Ordal agar colony morphology & Flat, round, with entire margins \\
Congo red absorption* & + \\
Growth on seawater media & + \\
Growth on nutrient agar & + \\
Growth on trypticase soy agar & + \\
Gliding motility & - \\
Flexirubin pigment type $\dagger$ & - \\
Glucose used as sole carbon and energy source & + \\
Acid produced aerobically from carbohydrates & - \\
Degradation of: & + \\
Gelatin & + \\
Casein & - \\
Starch & - \\
CM-cellulose & - \\
Agar & - \\
Pectin & - \\
Chitin & + \\
Aesculin & - \\
Deoxyribonucleic acid & - \\
Tyrosine & - \\
Brown diffusible pigment produced on tyrosine agar & - \\
Precipitate formed on egg-yolk agar & - \\
Hydrogen sulphide production & - \\
Cytochrome oxidase activity & - \\
Nitrate reduction & - \\
\hline
\end{tabular}

* Congo red absorption revealed the production of an extracellular galactosamine glycan.

$\dagger$ Flexirubin pigments were detected by using a $20 \%$ (w/v) $\mathrm{KOH}$ aqueous solution.

t Determined by the ONPG test. 
Table 2. API ZYM profiles and other test results for isolate $A 2 i^{\top}$ and the strains of the validly described Flavobacterium species that appear to be most related on the basis of $16 \mathrm{~S}$ rDNA sequence analysis

The values given are API ZYM scores: 0, no activity; 1, least activity; 5, most activity. +, Growth; -, no growth; NA, not applicable. For all strains, scores were 5 with 2-naphthyl-phosphate, and 0 with 2-naphthyl-butyrate, 2-naphthyl-myristate, $N$ benzoyl-DL-arginine-2-naphthylamide, naphthol-AS-BI- $\beta$-D-glucoronide, 6-Br-2-naphthyl- $\alpha$-D-mannopyranoside and 2-naphthyl$\alpha$-L-fucopyranoside. All strains grew on nutrient agar and trypticase soy agar.

\begin{tabular}{|c|c|c|c|c|c|}
\hline Test & Isolate $A 2 i^{\mathrm{T}}$ & $\begin{array}{l}\text { F. columnare } \\
\text { ATCC } 43622\end{array}$ & $\begin{array}{c}\text { F. johnsoniae } \\
\text { NCIMB } 10150\end{array}$ & 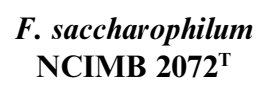 & $\begin{array}{c}\text { F. hydatis } \\
\text { ATCC } 29551^{1}\end{array}$ \\
\hline \multicolumn{6}{|l|}{ Substrate for hydrolysis } \\
\hline 2-Naphthyl-caprylate & 2 & 2 & 1 & 1 & 1 \\
\hline L-Leucyl-2-naphthylamide & 5 & 5 & 3 & 2 & 5 \\
\hline L-Valyl-2-naphthylamide & 5 & 5 & 1 & 1 & 5 \\
\hline L-Cystyl-2-naphthylamide & 1 & 3 & 1 & 0 & 3 \\
\hline $\mathrm{N}$-Glutaryl-phenylalanine-2-naphthylamide & 1 & 0 & 0 & 0 & 0 \\
\hline 2-Naphthyl-phosphate & 5 & 5 & 4 & 5 & 5 \\
\hline Naphthol-AS-BI-phosphate & 5 & 4 & 3 & 2 & 5 \\
\hline 6-Br-2-naphthyl- $\alpha$-D-galactopyranoside & 0 & 0 & 2 & 0 & 0 \\
\hline 2-Naphthyl- $\beta$-D-galactopyranoside & 0 & 0 & 1 & 1 & 0 \\
\hline 2-Naphthyl- $\alpha$-D-glucopyranoside & 0 & 3 & 3 & 1 & 5 \\
\hline 6-Br-2-naphthyl- $\beta$-D-glucopyranoside & 0 & 0 & 3 & 0 & 0 \\
\hline 1-Naphthyl- $N$-acetyl- $\beta$-D-glucosaminide & 0 & 1 & 2 & 1 & 5 \\
\hline Degradation of xylan & + & - & + & + & - \\
\hline Growth on MacConkey agar & - & + & + & - & + \\
\hline Growth at $25^{\circ} \mathrm{C}$ & - & + & + & + & + \\
\hline 16S rDNA similarity to $A 2 i^{\mathrm{T}}(\%)^{*}$ & NA & $96 \cdot 8$ & $96 \cdot 2$ & 95.9 & $95 \cdot 9$ \\
\hline Genomic DNA homology to $A 2 i^{\mathrm{T}}(\%)$ & NA & $21 \cdot 9$ & $29 \cdot 5$ & $33 \cdot 2$ & $35 \cdot 7$ \\
\hline
\end{tabular}

* 16S rDNA sequence similarities for $A 2 i^{\mathrm{T}}$ against $F$. columnare, $F$. johnsoniae, $F$. saccharophilum and $F$. hydatis were calculated for aligned sequences containing no spaces or undetermined base characters; the lengths of the $A 2 i^{\mathrm{T}}$ comparison sequence alignments were 1382, 1374, 1243 and $1377 \mathrm{bp}$, respectively.

could hydrolyse aesculin ( $\beta$-glucosidase activity) and gelatin (protease activity). The Voges-Proskauer test was negative, and there was no hydrogen sulphide production under any circumstances.

No precipitate was produced on egg-yolk agar, brown pigment was not secreted on tyrosine agar and there was no growth on MacConkey agar at any temperature. There seemed to be absorption of Congo red by $A 2 i^{\mathrm{T}}$ colonies, indicating the presence of extracellular galactosamine glycan; this may be the capsular substance around the cell (Fig. 1, bottom). The bacterium did not produce any acid or gas from glucose, fructose, xylose, mannitol or maltose. The main phenotypic properties of $A 2 i^{\mathrm{T}}$ are given in Table 1. The results of the API ZYM strips for $A 2 i^{\mathrm{T}}$ and the closest valid Flavobacterium species, on the basis of 16S rDNA sequence similarity, are displayed in Table 2.

Growth occurred on xylan, xylose, glucose, fructose, maltose, glycerol, tryptone, succinate, mannose, mannitol, laminarin, gelatin and casein as sole carbon and energy sources. However, there was no growth on CMcellulose, pectin, starch, chitin, agar, acetate, phenylacetate, arabinose, $N$-acetylglucosamine, gluconate, caprate, adipate, malate, citrate, tyrosine, galactose, inositol, lactose, pyruvate, raffinose, ribose, sucrose or trehalose. There was no evidence of growth under anaerobic conditions.

The doubling times in XMM broth at $0,5,10,15$ and $20{ }^{\circ} \mathrm{C}$ were measured and found to be $34 \cdot 8,28 \cdot 1,10 \cdot 9$, 9.6 and $13.1 \mathrm{~h}( \pm 10 \%)$, respectively. The optimum growth temperature was $15^{\circ} \mathrm{C}$ in $\mathrm{XMM}$ and the maximum growth temperature was $24^{\circ} \mathrm{C}$. The doubling times in $\mathrm{LB}$ broth at $15^{\circ} \mathrm{C}$ and at $\mathrm{pH}$ values of $5 \cdot 8$, $6 \cdot 1,6 \cdot 6,7 \cdot 1,7 \cdot 5,7 \cdot 8$ and $8 \cdot 1$ were determined and found to be $12 \cdot 5,7 \cdot 7,6 \cdot 9,4 \cdot 4,4 \cdot 3,10 \cdot 8$ and $13 \cdot 3 \mathrm{~h}( \pm 10 \%)$, respectively. The isolate had optimal growth at $\mathrm{pH} 7.5$ but could not grow at $\mathrm{pH} 5.5$ or $\mathrm{pH} 8.5$ in LB broth.

\section{Pigment characterization}

The $\mathrm{KOH}$ test was negative, indicating that the pigment was not flexirubin. The pigment was extracted and compared with carotenoid standards, using TLC on silica, and also with published $R_{F}$ values. Spectrophotometric analysis determined that its $\lambda_{\max }$ value in acteone $(453 \mathrm{~nm})$ matched the published value for zeaxanthin $(\beta, \beta$-carotene-3,3'-diol). 


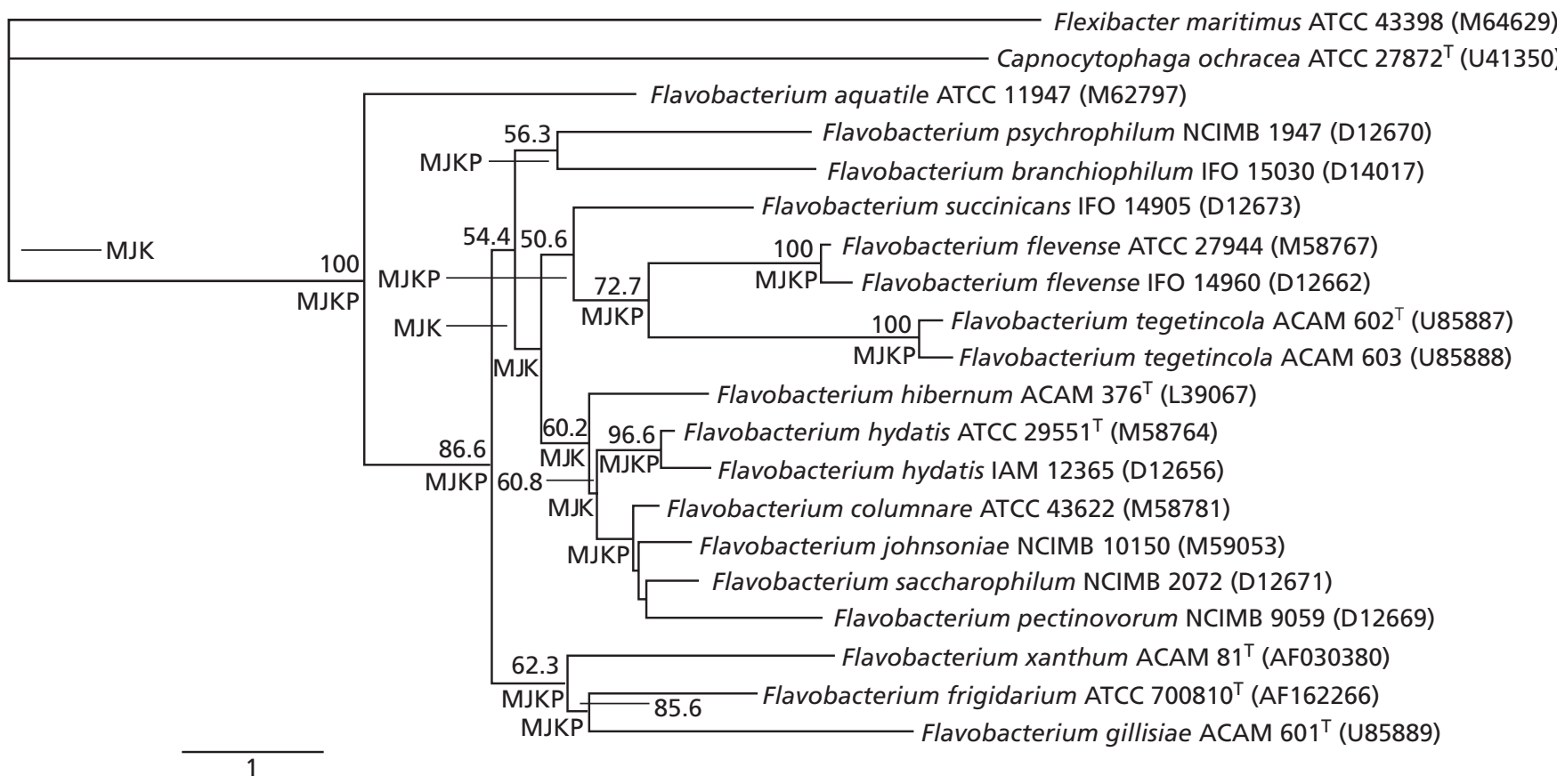

Fig. 2. Unrooted phylogenetic dendrogram for comparing the aligned $16 \mathrm{~S}$ rDNA sequences (1136 bases long) of the valid Flavobacterium species with $F$. frigidarium (see Methods). Bootstrap-confidence percentages are shown on the nodes if they occurred in more than $50 \%$ of the trees. ' $\mathrm{M}$ ', ' $\mathrm{J}$ ', ' $\mathrm{K}$ ' and ' $\mathrm{P}$ ' denote nodes that also occurred in maximum-likelihood, Jin \& Nei, Kimura two-parameter analyses (all with neighbour-joining) and an ordinary parsimony consensus tree of 1000 replicates, respectively. Bar, one nucleotide substitution per 100 nucleotides. Sequence accession numbers are in parentheses.

\section{Antibiotic susceptibility}

Isolate $A 2 i^{\mathrm{T}}$ was resistant to $10 \mu \mathrm{g}$ ampicillin $\mathrm{ml}^{-1}$, $200 \mu \mathrm{g}$ neomycin $\mathrm{ml}^{-1}, 1 \mathrm{mg}$ kanamycin $\mathrm{ml}^{-1}, 200 \mu \mathrm{g}$ gentamicin $\mathrm{ml}^{-1}$ and $200 \mu \mathrm{g}$ streptomycin $\mathrm{ml}^{-1}$. It showed sensitivity to $10 \mu \mathrm{g}$ erythromycin $\mathrm{ml}^{-1}, 50 \mu \mathrm{g}$ chloramphenicol $\mathrm{ml}^{-1}, 10 \mu \mathrm{g}$ tetracycline $\mathrm{ml}^{-1}$ and $10 \mu \mathrm{g}$ rifampicin $\mathrm{ml}^{-1}$. Filter-paper disks containing the following antibiotics showed zones of inhibition greater than $8 \mathrm{~mm}$ : fusidic acid, chloramphenicol, tetracycline, erythromycin and ampicillin. The novobiocin, penicillin $\mathrm{G}$, methicillin and streptomycin disks did not cause any growth inhibition.

\section{DNA G + C content and DNA-DNA hybridization}

The $\mathrm{G}+\mathrm{C}$ content of the genomic DNA of isolate $A 2 i^{\mathrm{T}}$ was determined to be $35 \mathrm{~mol} \%$. The genomic DNA of isolate $A 2 i^{\mathrm{T}}$ was $21 \cdot 9,29 \cdot 5,33 \cdot 2$ and $35 \cdot 7 \%$ similar to the genomic DNA of $F$. columnare ATCC 43622, F. johnsoniae NCIMB 10150, F. saccharophilum NCIMB 2072 and F. hydatis ATCC $29551^{\mathrm{T}}$, respectively.

\section{S rDNA analysis}

Phylogenetic analysis has shown that isolate $A 2 i^{\mathrm{T}}$ groups with members of the genus Flavobacterium (Fig. 2) as recently reorganized (Bernadet et al., 1996). The closest 16S rDNA sequence belongs to $F$. columnare ATCC 43622, whose sequence is $96.8 \%$ similar over 1382 bases. The second, third and fourth closest bacteria, respectively, were Flavobacterium johnsoniae NCIMB 10150, Flavobacterium saccharophilum NCIMB 2072 and Flavobacterium hydatis ATCC $29551^{\mathrm{T}}$ (Table 2). The fifth, sixth and seventh closest bacteria were Flavobacterium flevense ATCC 27944, F. hydatis IAM 12365 and Flavobacterium pectinovorum NCIMB 9059, being 95.8, 95.4 and 95.4 similar, respectively. The lengths of the sequences (after alignment against the $A 2 i^{\mathrm{T}} 16 \mathrm{~S}$ rDNA gene and removal of non-base characters) for each of these bacteria were 1356, 1238 and 1231 bases, respectively.

\section{Membrane composition}

The plasma membrane of $A 2 i^{\mathrm{T}}$ was composed of the following fatty acids: $3.66 \%$ branched $\mathrm{C}_{14} ; 1.6 \% \mathrm{C}_{14}$; $8.8 \%$ iso- $\mathrm{C}_{15} ; 15.1 \%$ anteiso- $\mathrm{C}_{15} ; 2.2 \%$ branched $\mathrm{C}_{15}: 1 ; 4.9 \% \mathrm{C}_{15} ; 1 \% \mathrm{C}_{15}: 1 ; 8.9 \%$ iso- $\mathrm{C}_{16} ; 1.6 \%$ anteiso- $\mathrm{C}_{16} ; 1 \cdot 4 \%$ branched $\mathrm{C}_{16}: 1 ; 3 \cdot 1 \% \mathrm{C}_{16} ; 43.5 \%$ $\mathrm{C}_{16}: 1$ cis $; 3 \cdot 13 \%$ unknown; $1 \% 16: 02-\mathrm{OH}$ and $1.7 \%$ 16:0 $3-\mathrm{OH}$.

\section{DISCUSSION}

Isolate $A 2 i^{\mathrm{T}}$ was isolated from marine sediment recovered from shallow waters surrounding Adelaide Island, Antarctica $\left(67^{\circ} 34^{\prime} \mathrm{S}, 68^{\circ} 07^{\prime} \mathrm{W}\right)$. The isolation 
of psychrophilic Antarctic bacteria was undertaken to investigate the enzymes that these microbes use to hydrolyse plant and algal cell wall polysaccharides. To date, there are few taxonomic or physiological data available concerning psychrophilic bacteria in the Antarctic habitat and which are involved in the degradation of complex polymers and carbon-cycling. $A 2 i^{\mathrm{T}}$ was isolated during a systematic search for xylanolytic, laminarinolytic, pectinolytic and cellulolytic bacteria in Southern Ocean near-shore sediments. In comparison to thermophiles, relatively few psychrophilic xylanolytic organisms have been described. The psychrophilic xylanolytic organisms that have been described include the anaerobic prokaryote Clostridium vincentii (Mounfort et al., 1997); the aerobic prokaryote Hymenobacter roseosalivarius (Hirsch et al., 1998) and the eukaryotes Cryptococcus TAE85 (Gerday et al., 1997) and Cryptococcus adeliae (Petrescu et al., 2000).

The phenotypic and genotypic features of isolate $A 2 i^{\mathrm{T}}$ suggest that it is a member of the genus Flavobacterium. This genus was originally defined only vaguely and included Gram-negative and Gram-positive species as well as aerobic and facultatively anaerobic species (Bergey et al., 1923). However, the genus has been extensively revised over the past 20 years. The first major revision limited it to Gram-negative, aerobic, non-motile rods with a $\mathrm{G}+\mathrm{C}$ content of $31-42 \mathrm{~mol} \%$ (Holmes et al., 1984). The second revision used DNA-rRNA hybridization experiments to allocate 10 species to the genus and to reorganize the family Flavobacteriaceae (Bernadet et al., 1996). This family contains a further 10 genera, including Flexibacter and Capnocytophaga (Jooste \& Hugo, 1999). DNA-DNA hybridization tests showed that several other Antarctic isolates (Flavobacterium hibernum, $F$. gillisiae, $F$. tegetincola and $F$. xanthum) are new species of the genus (McCammon \& Bowman, 2000; McCammon et al., 1998).

Comparative studies indicated that the bacterium was most closely related to $F$. columnare ( $96.8 \%$ similarity). The $16 \mathrm{~S}$ rDNA sequence of isolate $A 2 i^{\mathrm{T}}$ also had $>93 \%$ similarity to the other 13 valid Flavobacterium species; this was demonstrated for an alignment 1136 bases long with no non-base characters. The $16 \mathrm{~S}$ rDNA analysis does not reveal any other genera that could be sufficiently closely related to accommodate this isolate. The $\mathrm{G}+\mathrm{C}$ content of the genomic DNA $(35 \mathrm{~mol} \%)$ fits into the range of the genus (32$37 \mathrm{~mol} \%$ ). This supports the hypothesis that $A 2 i^{\mathrm{T}}$ is a member of the genus Flavobacterium as defined by Bernadet et al. (1996). In addition, the DNA-DNA hybridization tests comparing $A 2 i^{\mathrm{T}}$ with the four closest valid Flavobacterium species are sufficiently low (below $70 \%$ ) to allow the isolate to be designated as a new species with the name Flavobacterium frigidarium.

The bacterium shares some key phenotypic characteristics with many other members of the Flavobacterium genus (Table 1 and Bernadet et al., 1996). There is growth on NA and TSA, which is also seen for the four closest strains of the valid Flavobacterium species. No growth occurs on MacConkey agar, but $F$. saccharophilum NCIMB 2072 and Flavobacterium aquatile also do not grow on this medium (Holmes et al., 1984). The bacterium shows no gliding motility and cannot hydrolyse starch, CM-cellulose, agar, pectin or chitin, whereas $F$. johnsoniae, $F$. saccharophilum, F. hydatis ${ }^{\mathrm{T}}$ and $F$. flevense can hydrolyse some of these (Table 1 and Bernadet et al., 1996). It also has an API ZYM substrate-hydrolysis profile similar to those of the four closest Flavobacterium species (Table 2 ). Therefore, it seems appropriate that the isolate be placed in the Flavobacterium genus. The bacterium has a carotenoid pigment tentatively identified as zeaxanthin, which has also been seen in members of the Flavobacteriaceae (Schmidt et al., 1994).

The fatty acid complement of $A 2 i^{\mathrm{T}}$ is similar to those of the other Flavobacterium species. The main fatty acid in the membrane of $A 2 i^{\mathrm{T}}$ is $\mathrm{C}_{16}: 1$ cis $(43.5 \%)$; however, in most of the other Flavobacteria, iso- $\mathrm{C}_{15}: 0$ predominates (Bernadet et al., 1996). F. hibernum ACAM $376^{\mathrm{T}}$ has the most similar fatty acid profile; its main fatty acid is iso- $\mathrm{C}_{15}: 0(18.6 \%)$, the second most common one is $\mathrm{C}_{16}: 1(17 \cdot 7 \%)$, and anteiso- $\mathrm{C}_{15}: 0$ $(7.5 \%)$ is also present in higher concentrations than in nine of the other Flavobacterium species (McCammon et al., 1998). In addition, $A 2 i^{\mathrm{T}}$ does not seem to produce iso- $\mathrm{C}_{17}: 0 \quad 3-\mathrm{OH}, \mathrm{C}_{17}: 1 \omega 6 \mathrm{cis}$ and iso$\mathrm{C}_{17}: 1 \omega 9$ cis, which are commonly found in the other Flavobacterium species. There is no evidence of polyunsaturated fatty acids in the fatty acid profile, although these have been isolated from related bacteria such as Flavobacterium gondwanense (Bowman et al., 1998). It has been suggested that polyunsaturated fatty acid production has evolved in bacteria subjected to constant low temperatures and high pressures (Nichols et al., 1995). However, numerous monounsaturated and branched fatty acids, particularly 16:1cis (the most abundant cytoplasmic fatty acid in $A 2 i^{\mathrm{T}}$ ) are present. This profile is consistent with those of several other psychrophilic bacteria, in which such fatty acids contribute to the maintenance of membrane fluidity at low temperatures (Nichols et al., 1993).

Bernadet \& Grimont (1989) report antibiotic-sensitivity and $\mathrm{NaCl}$-tolerance results for $F$. columnare and $F$. psychrophilum, as well as $F$. flevense temperature data. The antibiotic-sensitivity pattern of isolate $A 2 i^{\mathrm{T}}$ is similar to those of $F$. columnare and $F$. psychrophilum, and $A 2 i^{\mathrm{T}}$ is resistant to very high concentrations of kanamycin. In contrast to $F$. columnare, $F$. psychrophilum and $F$. flevense, $A 2 i^{\mathrm{T}}$ could grow in AOB with up to $5 \% \mathrm{NaCl}(\mathrm{w} / \mathrm{v})$. F. flevense was also incapable of growth at $15^{\circ} \mathrm{C}$, in contrast to $A 2 i^{\mathrm{T}}$, for which this was the optimal growth temperature. $F$. columnare and $F$. psychrophilum are major fish pathogens (Bader \& Shotts, 1998); although the former has not been isolated in the Southern Hemisphere and has been isolated only in North America, Europe and Japan, the latter has been isolated in Tasmania (Chakroun et al., 1997). 


\section{Description of Flavobacterium frigidarium}

Flavobacterium frigidarium (fri.gid.ar.i'um. L. n. frigidarium one who bathes in cold water).

Non-sporulating, non-motile rods, $0 \cdot 8-2 \mu \mathrm{m}$ long and $0.5-0.7 \mu \mathrm{m}$ wide, with a thick capsule and pili. Aerobic, psychrophilic, halotolerant, xylanolytic and laminarinolytic. Gram-negative, non-flagellated and show no gliding motility. Produces the bright yellow carotenoid pigment zeaxanthin. Colonies on AOA are flat, round and entire. The $\mathrm{G}+\mathrm{C}$ content of the genomic DNA is $35 \mathrm{~mol} \%$. Growth occurs on xylan at $0-24{ }^{\circ} \mathrm{C}$; the minimum growth temperature on rich media is below $0{ }^{\circ} \mathrm{C}$. Grows at $\mathrm{pH} 5 \cdot 6-8 \cdot 4$, with an optimum of $\mathrm{pH} 7 \cdot 5$. Grows in $\mathrm{AOB}$ containing $0-5 \%(\mathrm{w} / \mathrm{v}) \mathrm{NaCl}$, in XeMM containing $0-4 \% \mathrm{NaCl}$, and in LB broth containing $0-9 \% \mathrm{NaCl}$. Grows on NA, TSA and seawater agar but not on MacConkey agar. Nitrate is not reduced, hydrogen sulphide is not produced under any conditions, and there is no indole production, no arginine dihydrolase, no urease, no DNase and no $\beta$ galactosidase. Hydrolyses aesculin and gelatin. VogesProskauer-negative. Does not produce any acid or gas from glucose, fructose, xylose, mannitol or maltose. No precipitate was produced on egg-yolk agar and no brown pigment was secreted on tyrosine agar. Resistant to the following in LB agar: $10 \mu \mathrm{g}$ ampicillin $\mathrm{ml}^{-1}, 200 \mu \mathrm{g}$ neomycin $\mathrm{ml}^{-1}, 1 \mathrm{mg}$ kanamycin $\mathrm{ml}^{-1}$, $200 \mu \mathrm{g}$ gentamicin $\mathrm{ml}^{-1}$ and $200 \mu \mathrm{g}$ streptomycin $\mathrm{ml}^{-1}$. Sensitive to $10 \mu \mathrm{g}$ erythromycin $\mathrm{ml}^{-1}, 50 \mu \mathrm{g}$ chloramphenicol $\mathrm{ml}^{-1}, 10 \mu \mathrm{g}$ tetracycline $\mathrm{ml}^{-1}$ and $10 \mu \mathrm{g}$ rifampicin $\mathrm{ml}^{-1}$. The following antibiotic disks caused zones of inhibition of more than $8 \mathrm{~mm}$ on LB agar: $10 \mu \mathrm{g}$ fusidic acid, $25 \mu \mathrm{g}$ chloramphenicol, $10 \mu \mathrm{g}$ tetracycline, $5 \mu \mathrm{g}$ erythromycin and $25 \mu \mathrm{g}$ ampicillin. Disks of novobiocin $(5 \mu \mathrm{g})$, penicillin $\mathrm{G}$ (1 IU), methicillin $(10 \mu \mathrm{g})$ and streptomycin $(10 \mu \mathrm{g})$ did not cause any growth inhibition. Chemo-organotrophic and utilizes xylan, laminarin, xylose, glucose, fructose, maltose, glycerol, tryptone, succinate, mannose, mannitol, gelatin and casein as sole carbon and energy sources. Does not utilize CM-cellulose, pectin, starch, chitin, agar, acetate, phenyl-acetate, arabinose, $N$-acetylglucosamine, gluconate, caprate, adipate, malate, citrate, tyrosine, galactose, inositol, lactose, pyruvate, raffinose, ribose, sucrose or trehalose. When grown up on NA, the substrates shown in Table 2 were or were not hydrolysed; when grown up on AOA, it additionally hydrolyses $N$-benzoyl-DL-arginine-2naphthylamide and 6-Br-2-naphthyl- $\beta$-D-glucopyranoside. Plasma membrane is composed of the following fatty acids: $3.66 \%$ branched $\mathrm{C}_{14} ; 1.6 \%$ $\mathrm{C}_{14} ; 8 \cdot 8 \%$ iso- $\mathrm{C}_{15} ; 15 \cdot 1 \%$ anteiso- $\mathrm{C}_{15} ; 2 \cdot 2 \%$ branched $\mathrm{C}_{15}: 1 ; 4.9 \% \mathrm{C}_{15} ; 1 \% \mathrm{C}_{15}: 1 ; 8.9 \%$ iso- $\mathrm{C}_{16} ; 1.6 \%$ anteiso- $\mathrm{C}_{16} ; 1.4 \%$ branched $\mathrm{C}_{16}: 1 ; 3 \cdot 1 \% \mathrm{C}_{16} ; 43.5 \%$ $\mathrm{C}_{16}$ : 1 cis; $3 \cdot 13 \%$ unknown; $1 \% 16: 02-\mathrm{OH}$ and $1.7 \%$ 16:0 3-OH. The single strain $A 2 i^{\mathrm{T}}$ (= ATCC $700810^{\mathrm{T}}$ $=$ NCIMB $13737^{\mathrm{T}}$ type strain) was isolated from shallow-water Southern Ocean sediment recovered near Adelaide Island, Antarctica $\left(67^{\circ} 34^{\prime} \mathrm{S}\right.$, $\left.68^{\circ} 07^{\prime} \mathrm{W}\right)$. The GenBank accession number for the
16S rDNA sequence of Flavobacterium frigidarium is AF162266.

\section{ACKNOWLEDGEMENTS}

The advice of Professor William Wade (Guy's Hospital, London) on 16S rDNA sequence analysis techniques, and the assistance of Alice Chapman (British Antarctic Survey) with sample collection, are gratefully acknowledged.

\section{REFERENCES}

Bader, J. A. \& Shotts, E. B. (1998). Determination of phylogenetic relationships of Flavobacterium psychrophilum (Flexibacter psychrophilus), Flavobacterium columnare (Flexibacter columnaris), and Flexibacter maritimus by sequence analysis of $16 \mathrm{~S}$ ribosomal RNA genes amplified by polymerase chain reaction. J Aquat Anim Health 10, 320-327.

Bergey, D. H., Harrison, F. C., Breed, R. S., Hammer, B. W. \& Huntoon, F. M. (1923). Genus II. Flavobacterium gen. nov. In Bergey's Manual of Determinative Bacteriology, pp. 97-117. Baltimore: Williams \& Wilkins.

Bernadet, J. F. \& Grimont, P. A. D. (1989). Deoxyribonucleic acid relatedness and phenotypic characterization of Flexibacter columnaris sp. nov., nom. rev., Flexibacter psychrophilus sp. nov., nom. rev., and Flexibacter maritimus Wakabayashi, Hikida, and Masumura 1986. Int J Syst Bacteriol 39, 346-354.

Bernadet, J. F., Segers, P., Vancanneyt, M., Berthe, F., Kersters, K. \& Vandamme, P. (1996). Cutting a Gordian knot: emended classification and description of the genus Flavobacterium, emended description of the family Flavobacteriaceae, and proposal of Flavobacterium hydatis nom. nov. (basonym, Cytophaga aquatilis Strohl and Tait 1978). Int J Syst Bacteriol 46, 128-148.

Bowman, J. P., McCammon, S. A., Lewis, T., Skerratt, J. H., Brown, J. L., Nichols, D. S. \& McMeekin, T. A. (1998). Psychroflexus torquis gen. nov., sp. nov., a psychrophilic species from Antarctic sea ice, and reclassification of Flavobacterium gondwanense gen. nov., comb. nov. Microbiology 144, 1601-1609.

Brenner, S. \& Horne, R. W. (1959). A negative staining method for high resolution electron microscopy of viruses. Biochim Biophys Acta 34, 103.

Cashion, P., Hodler-Franklin, M. A., McCully, J. \& Franklin, M. (1977). A rapid method for base ratio determination of bacterial DNA. Anal Biochem 81, 461-466.

Chakroun, C., Urdaci, M. C., Faure, D., Grimont, F. \& Bernardet, J.-F. (1997). Random Amplified Polymorphic DNA analysis provides rapid differentiation among isolates of the fish pathogen Flavobacterium psychrophilum and among Flavobacterium species. Dis Aquat Organ 31, 187-196.

Charnock, S. J., Lakey, J. H., Virden, R., Hughes, N., Sinnott, M. L., Hazelwood, G. P., Pickersgill, R. \& Gilbert, H. J. (1997). Key residues in subsite $\mathrm{F}$ play a critical role in the activity of Pseudomonas fluorescens subspecies cellulosa xylanase A against xylooligosaccharides but not against highly polymeric substrates such as xylan. J Biol Chem 272, 5, 2942-2951.

Collins, C. H., Lyne, P. M. \& Grange, J. M. (1991). Collins and Lyne's Microbiological Methods, 6th edn, pp. 68-107. Oxford: Butterworth-Heinemann.

De Ley, J., Cattoir, H. \& Reynaerts, A. (1970). The quantitative measurement of DNA hybridisation from renaturation rates. Eur J Biochem 12, 133-142. 
Escara, J. F. \& Hutton, J. R. (1980). Thermal stability and renaturation of DNA in dimethylsulphoxide solutions: acceleration of renaturation rate. Biopolymers 19, 1315-1327.

Fautz, E. \& Reichenbach, H. (1980). A simple test for flexirubintype pigments. FEMS Microbiol Lett 8, 87-91.

Feller, G., Payan, F., Theys, F., Qian, M., Haser, R. \& Gerday, C. (1994). Stability and structural analysis of $\alpha$-amylase from the Antarctic psychrophile Alteromonas haloplanctis A23. Eur J Biochem 222, 441-447.

Feller, G., Narinx, E., Arpigny, J. L., Aittaleb, M., Baise, E., Genicot, S. \& Gerday, C. (1996). Enzymes from psychrophilic organisms. FEMS Microbiol Rev 18, 189-202.

Felsenstein, J. (1993). PHYLIP (phylogenetic inference package), version 3.5.1. Seattle: Department of Genetics, University of Washington, USA.

Gerday, C., Aittaleb, M., Arpigny, J. L., Baise, E., Chessa, J.-P., Garsoux, G., Petrescu, I. \& Feller, G. (1997). Psychrophilic enzymes: a thermodynamic challenge. Biochim Biophys Acta 1342, 119-131.

Hirsch, P., Ludwig, W., Hethke, C., Sittig, M., Hoffmann, B. \& Gallikowski, C. A. (1998). Hymenobacter roseosalivarius gen. nov., sp. nov. from Continental Antarctic soils and sandstone: bacteria of the Cytophaga/flavobacterium/bacteroides line of phylogenetic descent. Syst Appl Microbiol 21, 374-383.

Holmes, B., Owen, R. J. \& McMeekin, T. A. (1984). Genus Flavobacterium. In Bergey's Manual of Systematic Bacteriology, vol. 1, pp. 353-361. Edited by N. R. Krieg \& J. G. Holt. Baltimore: Williams \& Wilkins.

Humphry, D. R., Cummings, S. P. \& Black, G. W. (1999). Carbohydrases as tools for understanding how cold enzymes are adapted to function at low temperatures. In Recent Advances in Carbohydrate Bioengineering, pp. 82-88. Edited by H. J. Gilbert, G. J. Davies, B. Henrissat \& B. Svensson. London: The Royal Society of Chemistry.

Huss, V. A. R., Festl, H. \& Schleifer, K. H. (1983). Studies on the spectrometric determination of DNA hybridization from renaturation rates. Syst Appl Microbiol 4, 184-192.

Jagannadham, M. V., Jayathirtha, R. \& Shivaji, S. (1991). The major carotenoid pigment of a psychrophilic Micrococcus roseus strain: purification, structure, and interaction with synthetic membranes. J Bacteriol 173, 24, 7911-7917.

Jahnke, K.-D. (1992). Basic computer program for evaluation of spectroscopic DNA renaturation data from GILFORD System 2600 spectrometer on a PC/XT/AT type personal computer. $J$ Microbiol Methods 15, 61-73.

Jooste, P. J. \& Hugo, C. J. (1999). The taxonomy, ecology and cultivation of bacterial genera belonging to the family Flavobacteriaceae. Int J Food Microbiol 53, 81-94.
Komagata, K. \& Suzuki, K. I. (1987). Lipid and cell wall analysis in bacterial systematics. Methods Microbiol 19, 161-207.

McCammon, S. A. \& Bowman, J. P. (2000). Taxonomy of Antarctic Flavobacterium species: description of Flavobacterium gillisiae sp. nov., Flavobacterium tegetincola sp. nov. and Flavobacterium xanthum sp. nov., nom. rev. and reclassification of [Flavobacterium] salegens as Salgentibacter salegens gen. nov., comb. nov. Int J Syst Evol Microbiol 50, 1055-1063.

McCammon, S. A., Innes, B. H., Bowman, J. P., Franzmann, P. D., Dobson, S. J., Holloway, P. E., Skerratt, J. H., Nichols, P. D. \& Rankin, L. M. (1998). Flavobacterium hibernum sp. nov., a lactose-utilizing bacterium from a freshwater Antarctic lake. Int $J$ Syst Bacteriol 48, 1405-1412.

Marmur, J. \& Doty, P. (1962). Determination of the base composition of deoxyribonucleic acid from its thermal denaturation temperature. J Mol Biol 5, 109-118.

Miller, G. L. (1959). Use of dinitrosalicylic acid reagent for determination of reducing sugars. Anal Chem 31, 426-428.

Mountfort, D. O., Rainey, F. A., Burghardt, J., Kaspar, H. F. \& Stackebrandt, E. (1997). Clostridium vincentii sp. nov., a new obligately anaerobic, saccharolytic, psychrophilic bacterium isolated from low-salinity pond sediment of the McMurdo Ice Shelf, Antarctica. Arch Microbiol 167, 54-60.

Nichols, D. S., Nichols, P. D. \& McMeekin, T. A. (1993). Polyunsaturated fatty acids in Antarctic bacteria. Antarct Sci 5, 149-160.

Nichols, D. S., Nichols, P. D. \& McMeekin, T. A. (1995). Ecology and physiology of psychrophilic bacteria from Antarctic saline lakes and sea ice. Sci Prog 78, 311-347.

Page, R. D. M. (1996). TREEVIEW: an application to display phylogenetic trees on personal computers. CABIOS 12, 357-358.

Petrescu, I., Lamotte-Brasseur, J., Chessa, J.-P., Ntarima, P., Claeyssens, M., Devreese, B., Marino, G. \& Gerday, C. (2000). Xylanase from the psychrophilic yeast Cryptococcus adeliae. Extremophiles 4, 137-144.

Russell, N. J. \& Nichols, D. S. (1999). Polyunsaturated fatty acids in marine bacteria - a dogma rewritten. Microbiology 145, 767-779.

Saitou, N. \& Nei, M. (1987). The neighbor-joining method: a new method for reconstructing phylogenetic trees. Mol Biol Evol 4, 406-425.

Schmidt, K., Connor, A. \& Britton, G. (1994). Analysis of pigments: carotenoids and related polyenes. In Chemical Methods in Prokaryotic Systematics, pp. 403-461. Edited by M. Goodfellow \& A. G. O’Donnell. Chichester: Wiley. 